\title{
Trophic structure of fish fauna along the longitudinal gradient of a first-order rural stream
}

\author{
Estrutura trófica da fauna de peixes ao longo do gradiente \\ longitudinal de um riacho rural de primeira ordem
}

\author{
Jardel Nimet ${ }^{1}$, Rosilene Luciana Delariva ${ }^{2}$, Luciano Lazzarini Wolff ${ }^{3}$ and \\ Jislaine Cristina da Silva ${ }^{4}$
}

\begin{abstract}
${ }^{1}$ Programa de Pós-graduação em Conservação e Manejo de Recursos Naturais, Universidade Estadual do Oeste do Paraná - Unioeste, Rua Universitária, 2069, CP 711, CEP 85819-110, Cascavel, PR, Brazil e- mail: jardel.nimet@gmail.com
\end{abstract}

2Programa de Pós-graduaçáo em Conservação e Manejo de Recursos Naturais, Centro de Ciências Biológicas e da Saúde, Universidade Estadual do Oeste do Paraná - Unioeste, Rua Universitária, 2069, CP 711, CEP 85819-110, Cascavel, PR, Brazil e-mail: rosilene.delariva@unioeste.br

${ }^{3}$ Centro de Ciências Biológicas e da Saúde, Universidade Estadual do Oeste do Paraná - Unioeste, Rua Universitária, 2069, CP 711, CEP 85819-110, Cascavel, PR, Brazil e-mail: luciano.wolff@unioeste.br

\section{${ }^{4}$ Programa de Pós-graduação em Ecologia de Ambientes Aquáticos Continentais, Universidade Estadual de Maringá - UEM, Av. Colombo, 5790, CEP 87020-900, Maringá, PR, Brazil e-mail: jislainebio@yahoo.com.br}

\begin{abstract}
Aim: This study evaluated the trophic structure of the fish assemblage along the longitudinal gradient of a first-order rural stream. Methods: Fish were sampled by electrofishing technique in December 2007, September 2008 and March 2009, at three stretch of the Itiz stream (headwater, middle and mouth). We sampled 1,255 individuals relating to 18 species. The categorization of trophic guilds was based on stomach content data of 1,096 individuals, analyzed according to the volumetric method, except for four species, which were classified according to the literature. To test the hypothesis of differences in the richness, abundance and biomass of trophic guilds along the headwater-mouth gradient, it was performed non-parametric statistical analysis of the dietary data. Was also calculated, the amplitude of trophic niche (Levins's index) for each guild. To summarize the composition and abundance of the trophic guilds along the longitudinal gradient, we applied a non-metric multidimensional scaling (NMDS). Results: We registered seven guilds: herbivorous, detritivorous, aquatic insectivorous, terrestrial insectivorous, invertivorous, omnivorous and piscivorous, the latter was exclusive to headwater and middle stretches. The omnivorous guild was not recorded in the headwater. Through PERMANOVA analysis it was found that the species richness of more specialized guilds (detritivorous and insectivorous terrestrial) and of generalist invertivorous increased, while less specialized guilds like aquatic insectivorous and herbivorous, decrease significantly in headwater-mouth direction. Except by the non-expected increase of insectivorous terrestrial and decrease of herbivorous downstream, the non-metric multidimensional scaling (NMDS) identified longitudinal variations in abundance and biomass of the guilds that agree with general patterns of fish guilds distribution along environmental gradients. Conclusion: These results suggest that the influence of environmental conditions around the stream (local particularities) also contributed to the formation of the observed patterns of trophic guilds along its longitudinal gradient.
\end{abstract}

Keywords: trophic guilds; richness; resource replenishment; generalist trophic; niche breadth.

Resumo: Objetivo: Este estudo avaliou a estrutura trófica de uma assembleia de peixes ao longo do gradiente longitudinal de um riacho rural de primeira ordem. Métodos: As amostragens foram realizadas em dezembro de 2007, setembro de 2008 e março de 2009, em três pontos do riacho Itiz (montante, meio e foz), através da técnica de pesca elétrica. 
Foram amostrados 1.255 indivíduos referentes a 18 espécies. A categorização das guildas tróficas foi baseada em dados de conteúdo estomacal de 1.096 indivíduos, analisados de acordo com o método volumétrico, exceto para quatro espécies, que foram classificadas de acordo com a literatura. Para testar a hipótese de que existem diferenças na riqueza, abundância e biomassa de guildas tróficas no sentido cabeceira-foz, foi realizada análise estatística náo-paramétrica sobre os dados da dieta. Calculou-se também, a amplitude de nicho trófico (Levins's index) para cada guilda. Para sumarizar os dados de composição e abundância das guildas ao longo do gradiente longitudinal, foi aplicado uma análise de escalonamento multidimensional não-métrico (NMDS). Resultados: Foram registradas sete guildas: herbívora, detritívora, insetívora aquática, insetívora terrestre, invertívora, onívora e piscívora, esta última sendo exclusiva para os trechos da cabeceira e meio do riacho. A guilda onívora não foi registrada na cabeceira. Através da análise PERMANOVA verificou-se que a riqueza de espécies das guildas mais especializadas (detritívora e insetívora terrestre) e da generalista invertívora, aumentou, enquanto as guildas menos especializadas (insetívora aquática e herbívora), diminuiu significativamente em direção cabeceira-foz. Exceto pelo aumento não esperado de insetívora terrestre e diminuiçáo de herbívora rio abaixo, o escalonamento multidimensional não-métrico (NMDS) identificou variaçôes longitudinais na abundância e biomassa das guildas que corroboram os padróes gerais de distribuiçáo das guildas tróficas dos peixes ao longo de gradientes ambientais. Conclusáo: Estes resultados sugerem que a influência das condiçóes ambientais do entorno do riacho (particularidades locais) também contribui para a formação dos padrôes de guildas tróficas observados ao longo do gradiente longitudinal.

Palavras-chave: guildas tróficas; riqueza; substituição de recursos; generalistas tróficos; amplitude de nicho.

\section{Introduction}

Fish classification into trophic guilds according to the use of food resources is a practice incorporated in feeding ecology studies from the concept revised by Gerking (1994). In addition to studies related to feeding, the classification into trophic guilds has been used as a tool for evaluating the longitudinal structure of fish assemblages (Angermeier \& Karr, 1983; Oberdorff et al., 1993; Ibañez et al., 2007; Ibañez et al., 2009) and the environmental quality (Jaramillo-Villa \& Caramaschi, 2008).

The structure of aquatic communities and the guild composition is influenced by changes in physiographic and hydrological characteristics along the river basin, which impose strong constraints on the distribution of tropical fish assemblages, in streams (Angermeier \& Karr, 1983; Pouilly et al., 2006) and rivers of large catchments (Pease et al., 2012). Furthermore, there are changes in input/processing ratio of organic matter and primary productivity along the system, which determine changes in the availability of food resources and consequently may interfere with the local composition of trophic guilds from temperate (Schlosser, 1982; Ibañez et al., 2007) and tropical streams (Wolff et al., 2013).

Longitudinal changes in the composition of fish trophic guilds have been reported in both temperate rivers (Schlosser, 1982; Oberdorff et al.,
1993, 2002), and tropical streams (Pouilly et al., 2006; Wolff et al., 2013), confirming the prediction of common longitudinal processes (Ibañez et al., 2007), which independent of taxonomy and evolutionary history of the species, converge the trophic structure of assemblages to similar spatial patterns (Ibañez et al., 2009). In this context, the main findings, based on the longitudinal availability of food resources, have been demonstrated, like as continuous, proportional changes from generalist (e.g. insectivorous, invertivorous) to more specialized guilds (e.g.detritivorous, piscivorous) along longitudinal gradients (Angermeier \& Karr, 1983; Oberdorff et al., 1993, 2002; Peres-Neto et al., 1995; Pouilly et al., 2006; Ibañez et al., 2007; Wolff et al., 2013).

Although these longitudinal changes are well documented, the observed patterns were established over large spatial scales (e.g. throughout the entire watershed, Pouilly et al., 2006; Ibañez et al., 2007). However, there is a gap in the knowledge related to the operation of spatial mechanisms and patterns generated at smaller scales, such as those originating from the short length of headwater streams (low-orders) (Ibañez et al., 2009; Wolff et al., 2013). This type of questioning gains theoretical foundation, since the water networks repeat units hierarchically (Poole, 2002), which may exhibit unique patterns of guild distribution and reveal local 
particularities, which eventually are disseminated when the watershed is analyzed in its entirety.

First-order streams have been particularly more affected by suppression of primary vegetation (Faria \& Marques, 1999; Casatti, 2010) for purposes of land use and occupation by agricultural activities. In particular, the basins of the north-northwestern Paraná State have undergone a rapid transformation from the 1970s, due to the mechanization and planting annual crops (especially soybeans and corn) (Campos, 1998). These changes in the landscape, in turn, could generate biases to the longitudinal distribution patterns of guilds, since local influences (Silva et al., 2012) would be reflected in variations in the supply of resources. Studies on the effects of the reduction and/or removal of riparian vegetation have shown that the trophic structure of fish assemblages can be altered by environmental homogenization (Lorion \& Kennedy, 2009; Zeni $\&$ Casatti, 2014). In such cases, only generalist or opportunistic species remain in the environment (Santos et al., 2015).

In this context, the present study analyzed the fish fauna of a first-order rural stream to test the hypothesis of differences in the presence, abundance and biomass of trophic guilds along the headwater-mouth gradient. Assuming that, when considering a smaller spatial scale, under the influence of agriculture in the surroundings, the trophic structuration of fish might not agree with the longitudinal distribution already generalized to other scales. Thus, the objectives of this study were:

i) to check differences in richness, abundance and biomass of trophic guilds along the headwater-mouth gradient in a first-order stream; and ii) to verify whether the degree of trophic specialization of the guilds increases along the gradient.

\section{Material and Methods}

\subsection{Study area}

The study was performed in Itiz stream, a first-order stream (Strahler, 1957), located in Marialva municipality, northern state of Paraná. It is a typical stream of the inland Atlantic Forest, being situated on the geological formation called Serra Geral, northeast of the third paranaense plateau, where the topography is slightly irregular. Itiz stream is small, approximately $3.8 \mathrm{~km}$ of extension, relatively narrow, with stretches of riffles alternating with backwaters and shallow pools, which combined with its low slope (approximately 50 meters between the headwater and mouth), fit it in a plain stream according to Uieda \& Castro
(1999). This stream flows into other tributaries of Pinguim stream, which flows into the Ivaí River. The Ivaí River watershed has an area of 36,899 $\mathrm{km}^{2}$ and a total course of $680 \mathrm{~km}$, and is the second-largest basin and the second-longest river in Paraná (Suderhsa, 2009).

Itiz stream is situated in a rural area (Figure 1) where the main economic activity is the cultivation of sugarcane, corn soybeans, grapes and wheat (IPARDES, 2016). The main physical characteristics and geographical coordinates of the three sampling stretch along the stream are listed in Table 1 and Figure 1.

\subsection{Fish collections}

Fish were collected at three stretches located in the headwater, middle and mouth regions, with an approximate distance of $1.2 \mathrm{~km}$ between each stretch, during December 2007, September 2008 and March 2009 (Figure 1). For the sampling, we used electrofishing with three passes of $30 \mathrm{~min}$ each, in stretches of $50 \mathrm{~m}$ per sampling stretch. The electrofishing equipment was powered by a portable generator (Honda, $2.5 \mathrm{~kW}, 220 \mathrm{~V}$, 3-4 A) connected to a DC transformer, with two electrified net rings (anode and cathode). Output voltage varied from 400 to $600 \mathrm{~V}$. For the sampling we installed blocking nets (mesh size $0.5 \mathrm{~mm}$ ) at the ends of each stretch to prevent any fish from escaping. After sampling, fish were anesthetized with benzocaine $(250 \mathrm{mg} / \mathrm{L})$ and fixed in $10 \%$ formalin. Fish were collected under license from the Instituto Brasileiro do Meio Ambiente e dos Recursos Naturais Renováveis (IBAMA; Process number 11253-1/2007).

Specimens were identified according to Graça \& Pavanelli (2007), and then preserved in 70\% ethanol. Each specimen captured was measured (standard and total lengths, in $\mathrm{cm}$ ), weighed (on an analytical balance) and then eviscerated. Voucher specimens were deposited in the fish collection of Nupélia (Núcleo de Pesquisas em Limnologia, Ictiologia e Aquicultura), of the State University of Maringá, Brazil.

\subsection{Diet analysis}

Gastric contents of 14 species based on all stomachs with food (fullness equal to or greater than 20\%) were identified under optical and stereoscopic microscopes to the lowest taxonomic level possible. For species with an undifferentiated stomach, the contents of the anterior third of the digestive tube were examined. For the analysis of 


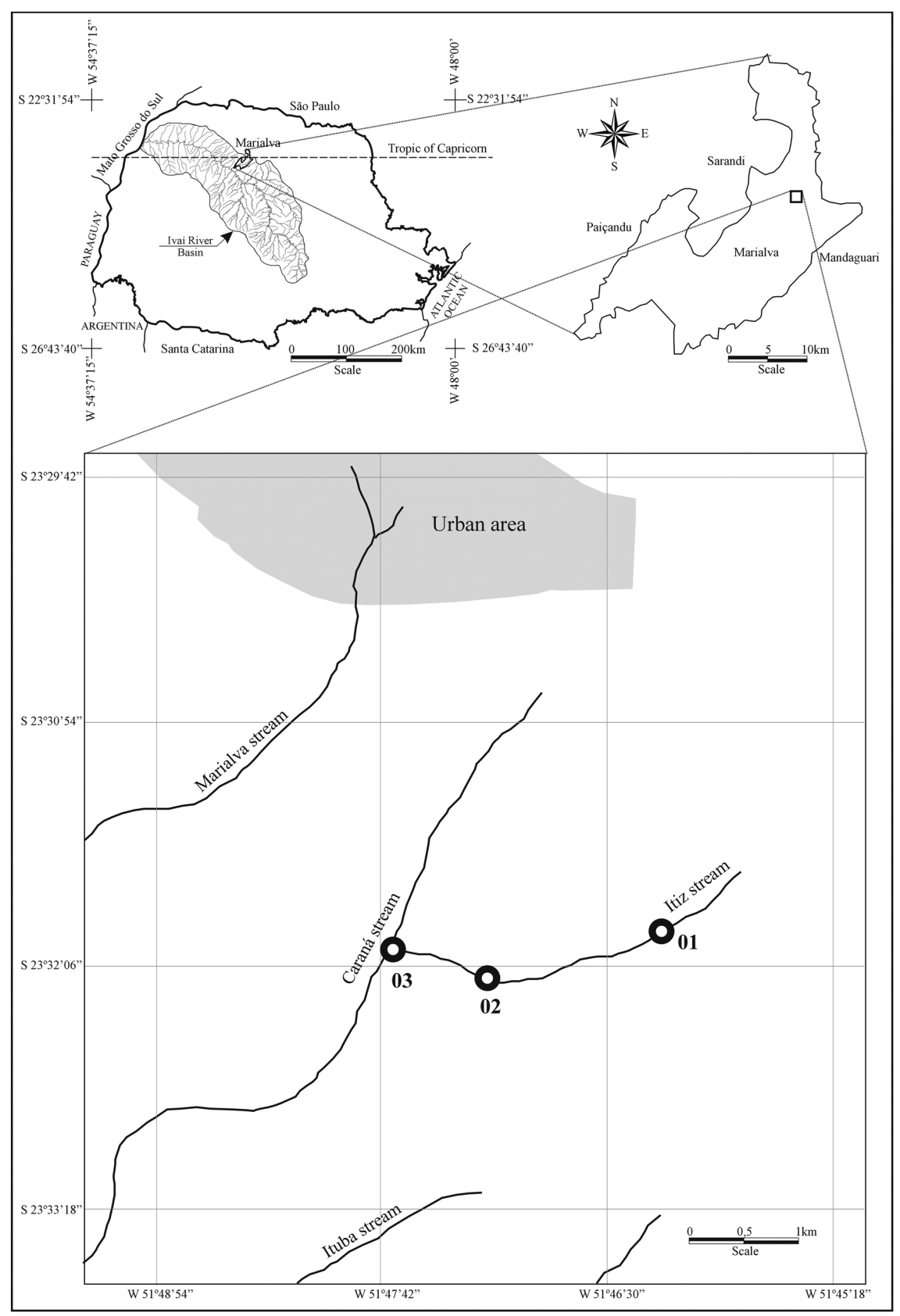

Figure 1. Map of Itiz stream in the Ivaí River basin, state of Paraná, Brazil, indicating sampling stretch $(01=$ headwater, $02=$ middle and $03=$ mouth).

stomach contents, we used only species for which we had a total of 5 or more samples. Food items were identified using the identification keys of Bicudo \& Bicudo (1970) for algae and of Mugnai et al. (2010) for invertebrates, and quantified according to the volumetric method; e.g. the total volume of a food item taken by the fish population is given as a percentage of the total volume of all stomach contents (Hyslop, 1980), using graduated test tubes and a glass counting plate (Hellawell \& Abel, 1971).
Trophic guilds were determined from the matrix of stomach contents, except for four species (Table 2), due small sample size, which were classified according to literature (Graça \& Pavanelli, 2007). For this analysis, the items identified were grouped into broader categories: aquatic invertebrates (Acarina, Decapoda, Cladocera, Conchostraca, Copepoda), aquatic insects (larvae of Coleoptera, Ephemeroptera, Plecoptera, Trichoptera, Simuliidae, Odonata nymphs and 


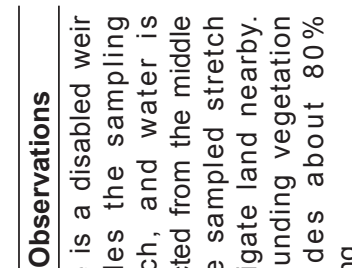

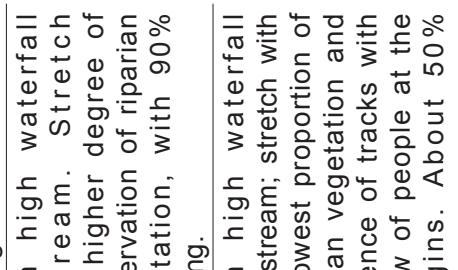
0. ब

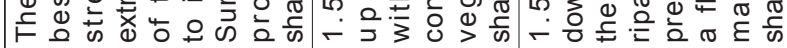

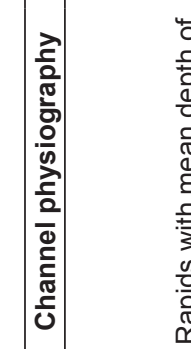

능우

융 $\frac{2}{3}$

둥 $\frac{0}{0}$

$\stackrel{Ð}{\varepsilon}$ 둘

彩

응 है है

षٓํํㅇ

욜

क

등 을

ญ व

㐫

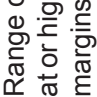

듬

등 응응

उ.

$\subseteq \varepsilon \subseteq \frac{\pi}{0}$

ผ

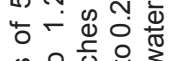

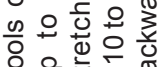

응 은융

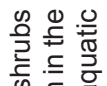

क

둥

o : 중

인

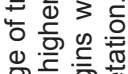

ॠ

믐 믐

응 둘

这

कi

㐫

எ

흥 है

웅

0
1
1
n.

क

จ

स

ฟे

กิ

1

웅

03

ำ

둥

ले हू

$\frac{1}{\pi}$
$\frac{\pi}{3}$
$\frac{\pi}{\pi}$
$\frac{1}{1}$
$\frac{1}{0}$
ำ

웅

$\circ$

+
1
$\stackrel{+}{+}$

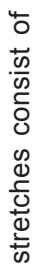

के

ธิ ฆ

过

3을

क

$\stackrel{\Phi}{=}$

무음

๙ᄄ

음

$\stackrel{\Phi}{ \pm}$

$\frac{0}{0}$

苍

옹

ำ

0

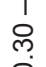

ì
I
ì

c)

遇

충 웅

ฟे हू

ํㅣㅁ

$\sum_{\substack{1 \\ 0}}^{0}$ 
remains of unidentified aquatic insects), terrestrial invertebrates (Oligochaeta and Araneae), terrestrial insects (Hymenoptera, Coleoptera), plants (leaves and seeds of vascular plants), detritus (particulate organic matter in different stages of decomposition and with mineral particles present), algae (Chlorophyta, Bacillariophyceae, Zygnemaphyceae) and fishes (Teleostei).

The categorization of trophic guild was performed according to the following criterion: more than $50 \%$ plant material (seeds and leaves) in the stomachs: herbivorous; more than 50\% detritus/sediment in the stomachs: detritivorous; more than $50 \%$ of aquatic insects in the stomachs: aquatic insectivorous; more than 50\% terrestrial insects in the stomachs: terrestrial insectivorous; similar proportions of aquatic organisms (insects and other invertebrates) and terrestrial (insects and other invertebrates: invertivorous; more than 50\% fish (including scales) in the stomachs: piscivorous (In this case, we use literature information); none of the above statements valid, and adding items from different origins (plant and animal): omnivorous.

\subsection{Statistical analysis}

Differences in the proportions of richness and abundance of trophic guilds along the longitudinal gradient were tested by a two-way permutational multivariate analysis of variance (two-way PERMANOVA, Anderson, 2001). This non-parametric test evaluates the significant difference between two or more groups, based on a distance measure, in this case the Bray-Curtis distance. PERMANOVA is sensitive to differences in multivariate dispersion, so we can check if dispersions are significantly different. To estimate the significance of this statistic, we used a Monte Carlo test with 10,000 permutations. The PERMANOVA were performed in the software PAST (version 2.17) (Hammer et al., 2001).

In order to show the relative level of dietary specialization and to associate this with the longitudinal gradient, the diet breadth of the guilds (except for piscivorous due small sample size) was calculated, with volume data, for the samples of the total individuals from each guild and stretch stream, using Levin's standardized index $(B): B_{i}=1 /(n-1)$. $\left[1 /\left(\sum_{j} p_{i j}^{2}\right)-1\right]$.

Where: $B i=$ Levin's standardized index for predator $i ; p_{i j}=$ proportion of diet of predator $i$ that is made up of prey $j$; $n=$ total number of food resources (Hurlbert, 1978). This index ranges from 0 (diet specialized in few prey items) to 1 (generalist diet). The data for diet breadth of the guilds were tested by a non-parametric ANOVA (Kruskal-Wallis test), recognizing that the assumptions of normality is not attended when the data are indices. The Fisher LSD multiple comparison test was applied to determine which median and thus which guilds differed from each other in diet breadth. These analyses were calculated with the software Statistica 7.0.

To summarize the composition and abundance of the trophic guilds along the longitudinal gradient, we applied a non-metric multidimensional scaling (NMDS) to examine the dispersion of the samples on a multidimensional scale (represented by a two dimensional graph) indicating the badness-of-fit, or "stress", of its representation (Clarke \& Gorley, 2001). Similarity matrices between samples were constructed using the Bray-Curtis index (Legendre \& Legendre, 1998) and data were standardized (square root) to minimize the discrepancy between samples. Data were randomized 100 times, and the stability criterion was 0.005 standard deviations in the stress after 17 iterations. This analysis was performed using the statistical package PRIMER-E v. 5.0 (Clarke \& Gorley, 2001).

\section{Results}

We collected 1,255 individuals of 18 species, three orders and seven families. Poecilia reticulata Peters, 1859 with $22.2 \%$, followed by Trichomycterus sp. (18.9\%) and Astyanax aff. paranae Eigenmann, 1914 (16.8\%) were the most abundant species in the catches, while Oligosarcus paranensis Menezes \& Géry, 1983, Hoplias sp. 2, Hypostomus cf. strigaticeps (Regan, 1908) and Hypostomus sp. were rare (Table 2). The middle was the most species rich stretch, with 17 species, while the headwater and mouth had 15 species each.

Besides the four species classified according to the literature, the stomach content of other 14 species $(\mathrm{n}=1,096)$ were analyzed for trophic classification (Table 2). Seven trophic guilds were registered: herbivorous, detritivorous, aquatic insectivorous, terrestrial insectivorous, invertivorous, omnivorous and piscivorous. The first five guilds occurred in all stretches, while the piscivorous guild was exclusive to the headwater and middle and the omnivorous guild, to the middle and mouth stretches (Table 2).

Overall, with respect to species variations in the composition of the guild along the gradient, Astyanax aff. fasciatus (Cuvier, 1819) was herbivorous in the headwater and middle and shifted to terrestrial insectivorous in the mouth. Astyanax aff. paranae 
Table 2. Taxonomic position (Reis et al., 2003) and trophic guilds of the species sampled in the Itiz stream.

\begin{tabular}{|c|c|c|c|c|c|c|}
\hline \multirow{2}{*}{ Order/Family/Species } & \multirow{2}{*}{ Vs } & \multirow{2}{*}{ Sn } & \multirow{2}{*}{$\mathrm{Aa}$} & \multicolumn{3}{|c|}{ Trophic guilds } \\
\hline & & & & Headwater & Midlle & Mouth \\
\hline \multicolumn{7}{|l|}{ CHARACIFORMES } \\
\hline \multicolumn{7}{|l|}{ Crenuchidae } \\
\hline Characidium aff. zebra Eigenmann, 1909 & NUP 11817 & 48 & 50 & Ain & Ain & Ain \\
\hline \multicolumn{7}{|l|}{ Characidae } \\
\hline Astyanax aff. fasciatus (Cuvier, 1819) & NUP 11797 & 77 & 78 & Her & Her & Tin \\
\hline Astyanax aff. paranae Eigenmann, 1914 & NUP 11794 & 176 & 211 & Her & Her & Omn \\
\hline Astyanax bockmanni Vari \& Castro, 2007 & NUP 11793 & 48 & 49 & Her & Omn & Her \\
\hline Bryconamericus aff. iheringi (Boulenger, 1887) & NUP 11791 & 63 & 65 & $\operatorname{lnv}$ & $\operatorname{lnv}$ & Inv \\
\hline Bryconamericus stramineus Eigenmann, 1908 & NUP 11818 & 16 & 20 & Tin & Tin & Tin \\
\hline Oligosarcus paranensis Menezes \& Géry, 1983 & NUP 11788 & * & 1 & - & Pis & - \\
\hline \multicolumn{7}{|l|}{ Erythrinidae } \\
\hline Hoplias sp. 2 & NUP 11828 & * & 2 & Pis & Pis & - \\
\hline \multicolumn{7}{|l|}{ SILURIFORMES } \\
\hline \multicolumn{7}{|l|}{ Trichomycteridae } \\
\hline Trichomycterus sp. & NUP 11800 & 186 & 237 & Ain & Ain & Ain \\
\hline \multicolumn{7}{|l|}{ Loricariidae } \\
\hline Hisonotus sp. & NUP 11808 & 28 & 34 & Det & Det & Det \\
\hline Rineloricaria aff. pentamaculata Langeani \& Araújo, 1994 & NUP 11815 & 81 & 84 & Det & Det & Det \\
\hline Hypostomus ancistroides (Ihering, 1911) & ------- & 66 & 72 & Det & Det & Det \\
\hline Hypostomus cf. strigaticeps (Regan, 1908) & NUP 11814 & * & 1 & - & - & Det \\
\hline Hypostomus sp. & NUP 11804 & * & 4 & - & Det & Det \\
\hline \multicolumn{7}{|l|}{ Heptapteridae } \\
\hline Cetopsorhamdia iheringi Schubart \& Gomes, 1959 & NUP 11816 & 6 & 12 & Ain & Ain & - \\
\hline Imparfinis schubarti (Gomes, 1956) & NUP 11799 & 8 & 16 & Ain & Ain & Inv \\
\hline $\begin{array}{l}\text { Rhamdia quelen } \\
\text { (Quoy \& Gaimard, 1824) }\end{array}$ & NUP 11805 & 24 & 40 & $\operatorname{lnv}$ & $\operatorname{lnv}$ & Inv \\
\hline \multicolumn{7}{|l|}{ CYPRINODONTIFORMES } \\
\hline \multicolumn{7}{|l|}{ Poeciliidae } \\
\hline Poecilia reticulata Peters, 1859 & NUP 11807 & 269 & 279 & Det & Det & Det \\
\hline Total number & & 1096 & 1255 & & & \\
\hline
\end{tabular}

$\mathrm{Vs}=$ Vouchers specimens; $\mathrm{Sn}=$ number of analyzed stomach contents; $\mathrm{Aa}=\mathrm{Absolute}$ abundance. Trophic guilds (Her= Herbivorous; Ain= Aquatic insectivorous; Tin= Terrestrial insectivorous; Inv= invertivorous; Omn= Omnivorous; Pis= Piscivorous; Det= detritivorous). ${ }^{*}=$ without analysis of stomach contents due small sample size.

was herbivorous in the headwater and middle and shifted to omnivorous in the mouth. Astyanax bockmanni Vari \& Castro, 2007 was herbivorous in the headwater and mouth, and omnivorous in the middle. Imparfinis schubarti (Gomes, 1956) was aquatic insectivorous in the headwater and middle, and invertivorous in the mouth (Table 2).

Such as species richness, the number of guilds was higher in the middle $(\mathrm{n}=7)$, compared with the headwater and mouth that had six guilds each. The richness of detritivorous, terrestrial insectivorous and invertivorous tended to increase in the headwater-mouth direction, while the richness of the aquatic insectivorous and herbivorous guilds decreased (Figure 2). These differences in the proportions of richness were confirmed by two-way PERMANOVA that evidenced significant differences in the interaction between guild and stretch $(\mathrm{F}=2.25 ; \mathrm{p}=0.0089)$, between guilds $(\mathrm{F}=8.9 ; \mathrm{p}=0.0001)$ and between all guilds of different sampled stretches $(F=3.04 ; p=0.032)$.

Differences in the average diet breadth between guilds were significant (Kruskal-Wallis test $=16.74 ; \mathrm{p}<0.01)$. A multiple pairwise test (LSD test $\mathrm{p}<0.05)$ indicated that detritivorous and terrestrial insectivorous guilds were significantly more-specialized and invertivorous was more generalist (Figure 3). Herbivorous, aquatic insectivorous and invertivorous guilds tended to be more generalist according to the headwater-mouth gradient (higher $B$ values), while the other guilds showed no longitudinal pattern (Figure 3).

The NMDS demonstrated that, detritivorous and aquatic insectivorous guilds were the most abundant and spatially similar along the gradient (Figure 4). For biomass, the analysis highlighted 
the guilds herbivorous and invertivorous in the headwater and herbivorous in the middle, but a low spatial similarity between all guilds (Figure 4).

Considering each guild separately, omnivorous and terrestrial insectivorous tended to increase in abundance and biomass, while detritivorous increased only in biomass along the longitudinal gradient. On the other hand, herbivorous tended to decrease in abundance and biomass and aquatic insectivorous only in abundance. The invertivorous decreased in middle and increased in mouth for both, abundance and biomass, thereby showing no longitudinal distribution pattern (Figure 4).

Variations observed in the NMDS were confirmed by two-way PERMANOVA, with significantly different results for the abundance between guilds and stretches $(F=1.6 ; \mathrm{p}=0.0391)$, between guilds $(\mathrm{F}=7.1 ; \mathrm{p}=0.0001)$ and between all the guilds of the different sampled stretches $(\mathrm{F}=2.2$; $\mathrm{p}=0.0493)$, and for the biomass between guilds and stretches $(\mathrm{F}=1.7 ; \mathrm{p}=0.0239)$, between guilds $(\mathrm{F}=4.5 ; \mathrm{p}=0.0002)$ and between all the guilds of the different stretches $(\mathrm{F}=2.8 ; \mathrm{p}=0.0228)$.

\section{Discussion}

Despite the small size of the Itiz stream, the number of species registered (18) was considerably higher than in other first-order streams of the region, which contain four to five species (Cionek et al.,
2012). However, this value is similar to that found by Casatti (2005) (18 species), in a preserved stream of the State Park Morro do Diabo, São Paulo State. Although these plain streams apparently do not show a common regional pattern for the number of species, the high richness observed in the present study represented for seven trophic guilds, which allowed us to draw ecological inferences based on longitudinal distribution patterns of these guilds, even in the short length scale of a first-order stream.

Except for the detritivorous guild, regardless of the stretch occupied in the stream, the fish assemblage tended to be dominated by generalist guilds, that is, with no significant trophic specialization (Esteves \& Aranha, 1999; Abelha et al., 2001). This pattern has been recurrent in several plain streams (Casatti, 2002) and headwater streams (Wolff et al., 2013; Cruz et al., 2013), most probably due to the variation in the physical structure of these systems and consequently on the availability of food resources, selecting, ultimately, flexible feeding habits (Abelha et al., 2001). Moreover, the presence of piscivorous (e.g. specialized guild), occurred sporadically and did not reveal an expected pattern of longitudinal increase (Angermeier \& Karr, 1983; Peres-Neto et al., 1995; Pouilly et al., 2006). This is not only due to the low probability of catching the species composing this guild, but also because these species probably do not maintain locally established

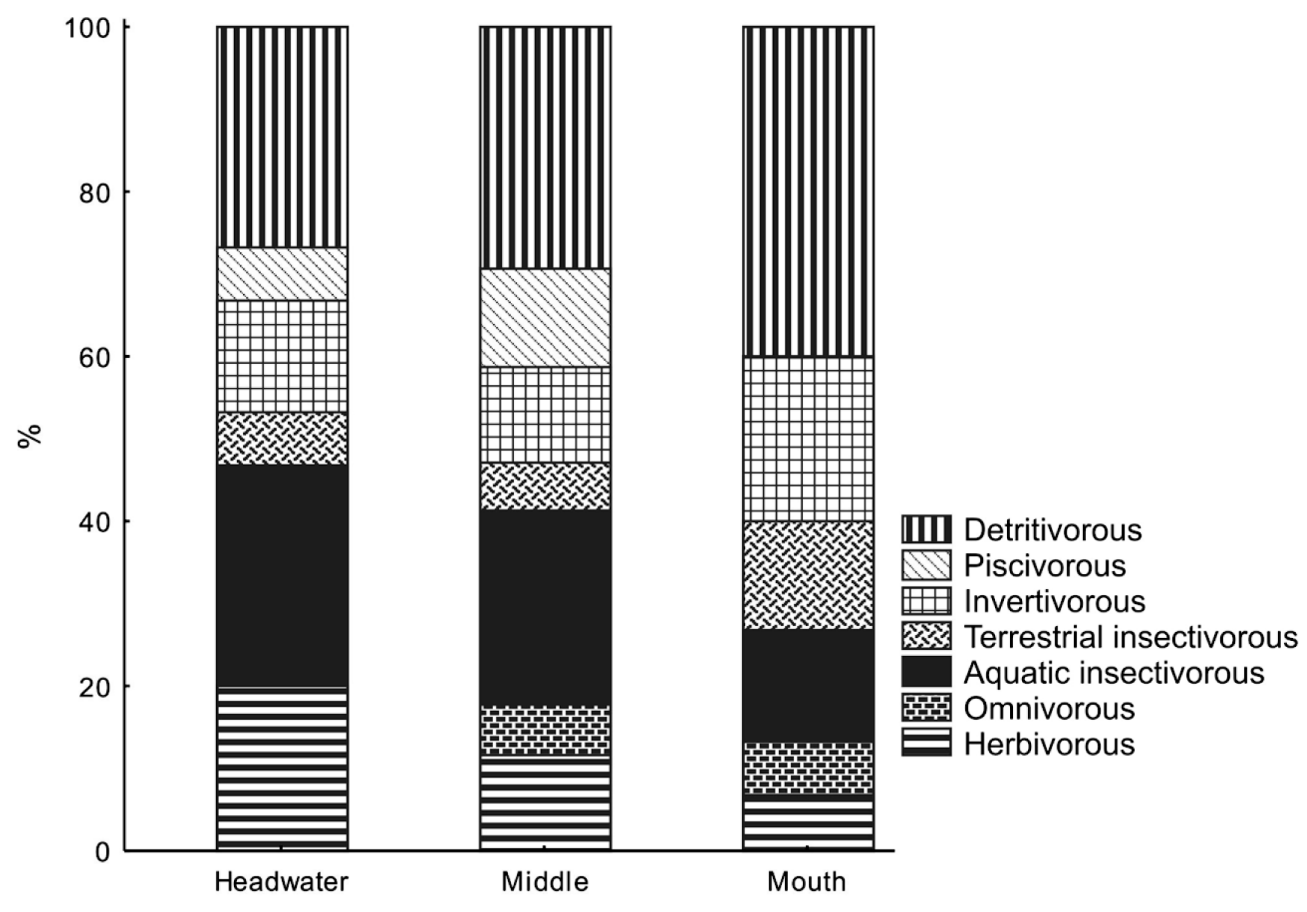

Figure 2. Relative frequency of the species richness according to trophic guild along the longitudinal gradient Itiz stream. 


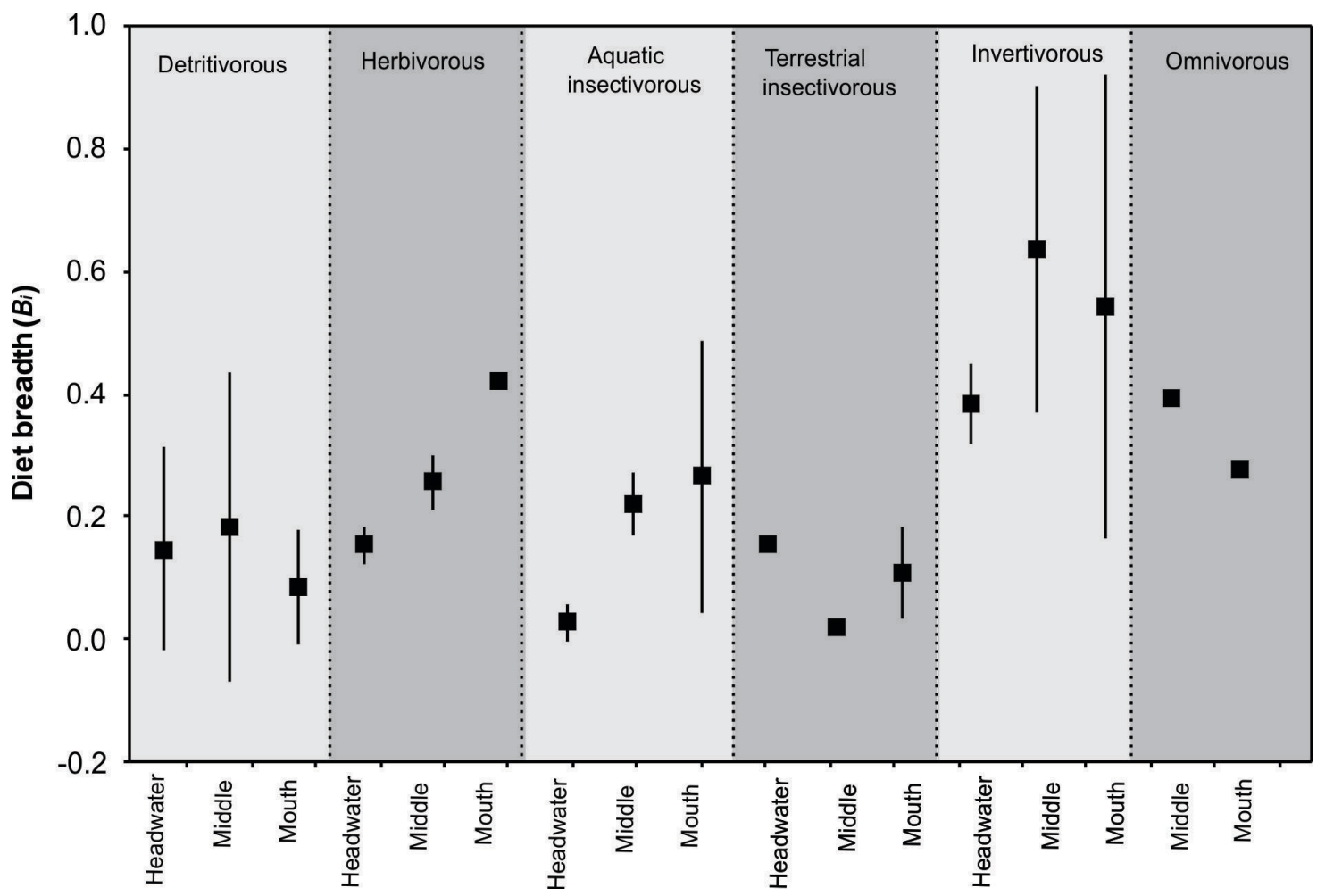

Figure 3. Mean \pm standard deviation of the diet breadth $(B)$ of fish trophic guilds along the longitudinal gradient of the Itiz stream.

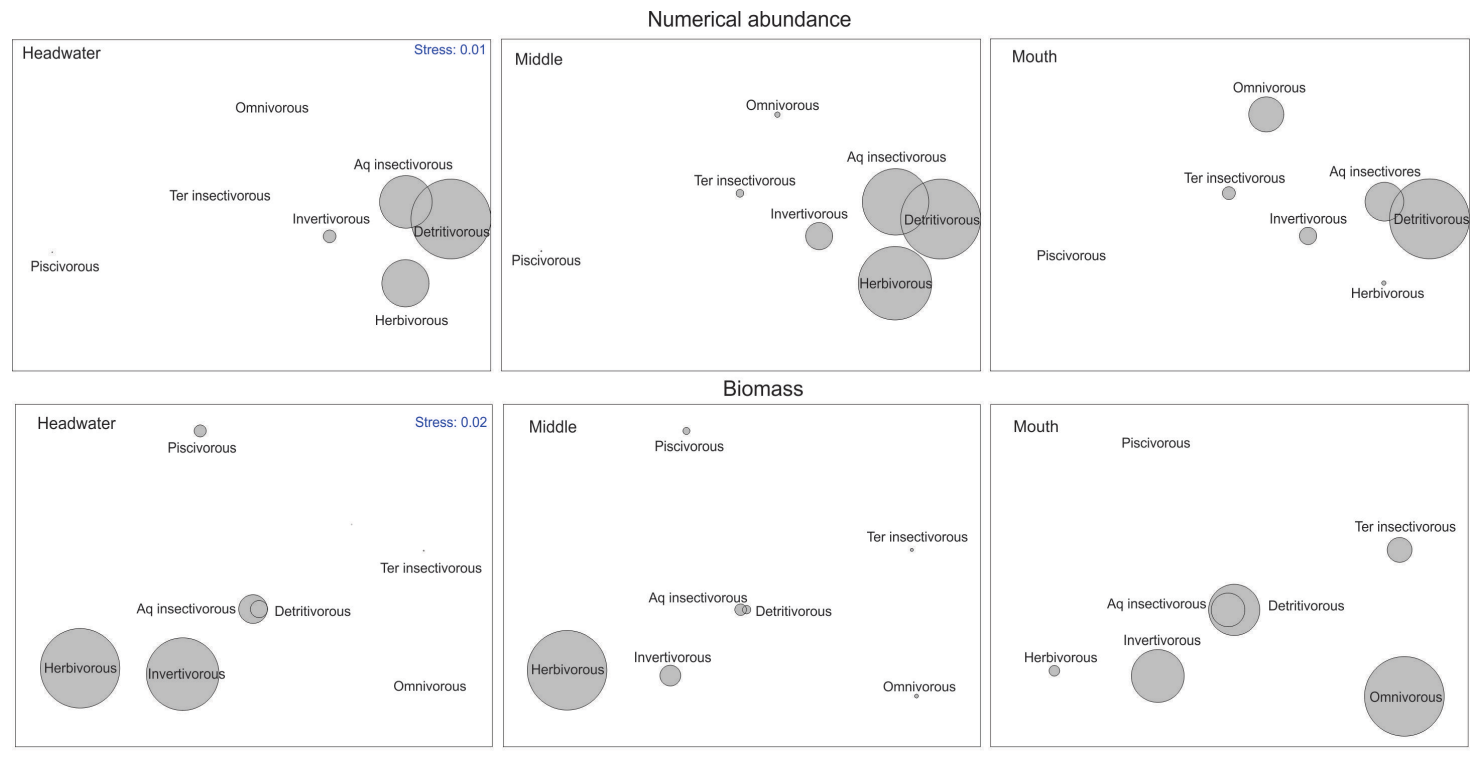

Figure 4. Multidimensional scaling plots of trophic guilds of the Itiz stream. Above the abundance and below the biomass of the guilds showing according to circle size their predominance a long gradient headwater-mouth.

populations in small streams. In last situation, the amount of energy in local food webs would be insufficient to maintain a high number of top species (Oberdorff et al., 2002; Ibañez et al., 2009).
In the case of specific variations in guild composition, characins (Astyanax spp.) represented the group that most shifted into different guilds (e.g. especially between herbivorous and omnivorous) 
along the stream. Among freshwater teleosts, this group shows a remarkable food plasticity (Abelha et al., 2001; Andrian et al., 2006; Silva et al., 2014), which makes difficult a generalization into guilds (Wolff et al., 2009), since these organisms respond immediately to changes in the resource supply (Vitule et al., 2008; Wolff et al., 2009; Mazzoni et al., 2010). However, in addition to longitudinal effects, our results may have been influenced by the surrounding physiography, since it is a rural stream where the stretches of headwater and middle exhibited less altered riparian vegetation. In turn, this coincided with the herbivorous habit presented by these characins at the headwater and middle.

In relation to the number of trophic guilds, the middle was the most diverse stretch, coinciding with the greatest richness of species caught. These results confirm those reported by Wolff et al. (2013), and suggest that, in the context of longitudinal gradient, the intermediate environments are more heterogeneous and have varied availability of food resources. This finding, thus enabling the coexistence of a greater number of species segregated into different guilds. Fish diet data of the Itiz stream (Silva et al., 2012) endorse this statement, since the middle stretch had the lowest values of dietary overlap, supporting thus, the trophic segregation mechanism in heterogeneous environments (Ross, 1986).

Following a longitudinal structuring model, some of the changes in the composition of guilds, as the relative increase of detritivorous and the reduction of aquatic insectivorous downstream, corroborate with other empirical data of the longitudinal distribution (Angermeier \& Karr, 1983; Pouilly et al., 2006; Wolff et al., 2013). In the case of detritivorous guilds (composed mainly by the addition of other detritivorous armored catfishes loricariids), it is possible to infer that the longitudinal increase in the availability of fine organic matter (like detritus), fragmented by hydrological activity and macroinvertebrates downstream, had favored their increase. On the other hand, the relative decrease of aquatic insectivorous, was probably related to a longitudinal reduction in the supply of aquatic insect larvae, such as Ephemetoptera, Trichoptera and Plecoptera. This observation is supported by data on the distribution and structure of the benthic community assessed in the same study area (Bagatini et al., 2012). The reduced flow and diversity of rocky substrates with consequent structural homogenization of the environment was especially evident in the mouth of the stream.

Although the tendencies mentioned above are statistically supported, other results observed herein did not follow a longitudinal pattern. This is the case of terrestrial insectivorous and invertivorous that, unlike that reported by Wolff et al. (2013) and Ibañez et al. (2009), increased downstream, and herbivorous that, unlike Angermeier \& Karr (1983) and Ibañez et al. (2007), decreased along the longitudinal gradient. In this case, the lack of a general pattern for the distribution of trophic guilds is probably associated with the spatial scale (e.g. order of the stream), contrary to what is predicted for the river system as a whole (Peres-Neto et al., 1995; Pease et al., 2012; Melles et al., 2012). Furthermore, along the approximately $3 \mathrm{~km}$ of the Itiz stream length, there is little variation in altitude and consequently in channel geomorphology, differently from Wolff et al. (2013), who found consistent patterns in a coastal Atlantic stream, similar in length, but with a strong environmental gradient. This reinforces the proposition that the distribution of fish assemblages along headwater systems (especially first-order plain streams) is dominated by generalist guilds and that the patterns presented here may be reflecting just the results of the high watershed segment.

For the degree of trophic specialization, detritivorous and terrestrial insectivorous were significantly more specialized. In the first case, our data corroborate those of Pouilly et al. (2006) and Wolff et al. (2013), and demonstrate the consistency in the diet of these species, since they exhibit exclusive morphological specializations (Bowen, 1983), which allow the assimilation of low digestible material in the detritus. Morover, the degree of specialization of terrestrial insectivorous does not correspond to that usually is found in the literature (Barreto \& Aranha, 2006; Wolff et al., 2013), because they often feed on a wide range of resources. Farther, this may be related to the degradation of riparian vegetation (especially in the mouth) and a consequent reduction in the varied supply of allochthonous insects. On the other hand, invertivorous were significantly more generalist, increasing their occurrence in the mouth, which, together with the results of other guilds, did not express any trend for longitudinal increase in the trophic specialization.

Detritivorous and aquatic insectivorous showed the highest abundances, and presented greater similarity and a common structure along the 
gradient. Thus, the predominance of these two guilds (e.g. basal trophic guilds) would reflect in the shortening of local food webs, resulting in a direct and relatively efficient conversion of primary productivity into fish biomass (Winemiller et al., 2008). In herbivorous, this assumption was indeed verified, especially in the headwater and middle, since their greater abundance resulted in increased biomass. Nevertheless, the same was not observed for detritivorous and aquatic insectivorous, because they are small sized species $(15-70 \mathrm{~mm})$, as P. reticulata and Trichomycterus sp., whose increase in abundance does not reflect directly in a significant increase in biomass.

Additionally, despite evidence of higher autochthonous primary productivity in tropical streams (Davies et al., 2008), it is generally agreed that allochthonous resources are essential for fish of neotropical streams (Lowe-McConnell, 1999; Esteves \& Aranha, 1999; Cruz et al., 2013). In this sense, the structure and complexity of the vegetation surrounding the Itiz stream probably was so important in structuring the abundance and biomass of guilds, as the longitudinal changes predicted by the availability of food resources. In this case, the longitudinal increase of omnivorous and terrestrial insectivorous and decrease of herbivorous, especially in the mouth, resulted in the high consumption of a single item, Hymenoptera (ants), attesting the little varied supply of resources in the mouth, associated with its low complexity of the surroundings and the stream channel. On the other hand, the anthropogenic effect on the environment, mainly by agriculture, probably also influenced the significant differences in structure among the guilds and sampling stretches, generating high dissimilarity of inter-guilds proportions.

In short, it can be concluded that the longitudinal structure patterns of fish trophic guilds of the Itiz stream are explained both by the availability of resources along the gradient (Oberdorff et al., 1993; Peres-Neto et al., 1995; Pouilly et al., 2006; Melles et al., 2012), and by homogenization of its surroundings. The results revealed that predictable longitudinal changes in guild composition occur even at a reduced spatial scale of a first order stream. However, environmental instability and, possibly, changes in food sources, especially allochthonous, along the fluvial continuum constrain the trophic groups within the community; favor the predominance of generalist guilds, confirming our hypothesis. In addition, significant variations observed in abundance and biomass among the guilds and stretches suggest that trophic interactions occur differently in response at a local level to the effects of environmental alteration along the gradient.

\section{Acknowledgements}

We thank Unicesumar for providing logistical support for sampling and analyzing materials. We also thank all our colleagues for helping in field work.

\section{References}

Abelha, M.C.F., Agostinho, A.A. and GOULART, E. Plasticidade trófica em peixes de água doce. Acta Scientiarum. Biological Sciences, 2001, 23(2), 425-434.

ANDERSON, M.J. A new method for non-parametric multivariate analysis of variance. Austral Ecology, 2001, 26, 32-46. http://dx.doi.org/10.1111 /j.1442-9993.2001.01070.pp.x.

ANDRIAN, I.F., PERETTI, D. and LAMBRECHT, D. Recursos alimentares explorados por Astyanax (Characiformes, Characidae) em diferentes bacias hidrográficas. Arquivos do Mudi, 2006, 10(1), 21-27.

ANGERMEIER, P.L. and KARR, J.R. Fish communities along environmental gradients in a system of tropical streams. Environmental Biology of Fishes, 1983, 9(2), 117-135. http://dx.doi.org/10.1007/BF00690857.

BAGATINI, Y.M., DELARIVA, R.L. and HIGUTI, J. Benthic macroinvertebrate community structure in a stream of the north-west region of Paraná State, Brazil. Biota Neotropica, 2012, 12(1), 307-317. http:// dx.doi.org/10.1590/S1676-06032012000100023.

BARRETO, A.P. and ARANHA, J.M.R. Alimentação de quatro espécies de Characiformes de um riacho da Floresta Atlântica, Guaqueçaba, Paraná, Brasil. Revista Brasileira de Zoologia, 2006, 23(3), 779-788. http:// dx.doi.org/10.1590/S0101-81752006000300023.

BICUDO, C.E.M. and BICUDO, R.M.T. Algas de Aguas Continentais Brasileiras. Chave Ilustrada Para Identificação de Gêneros. São Paulo: Fundação Brasileira para o Desenvolvimento do Ensino de Ciências, 1970. 228 p.

BOWEN, S.H. Detrivory in neotropical fish communities. Environmental Biology of Fishes, 1983, 9(2), 137-144. http://dx.doi.org/10.1007/BF00690858.

CAMPOS, J.B. Desmatamentos no Paraná. Cadernos da Biodiversidade, 1998, 1(1), 1-2.

CASATTI, L. Alimentação dos peixes em um riacho do Parque Estadual Morro do Diabo, bacia do Alto Rio Paraná, sudeste do Brasil. Biota Neotropica, 2002, 2(2), 1-14. http://dx.doi.org/10.1590/S167606032002000200012.

CASATTI, L. Alteraçôes no Código Florestal Brasileiro: impactos potenciais sobre a ictiofauna. Biota 
Neotropica, 2010, 10(4), 31-34. http://dx.doi. org/10.1590/S1676-06032010000400002.

CASATTI, L. Fish assemblage structure in a first order stream, southeastern Brazil: longitudinal distribution, seasonality, and microhabitat diversity. Biota Neotropica, 2005, 5(1), 75-86. http://dx.doi. org/10.1590/S1676-06032005000100009.

CIONEK, V.M., SACRAMENTO, P.A., ZANATTA, N., OTA, R.P., CORBETTA, D.F. and BENEDITO, E. Fishes from first order streams of lower Paranapanema and Ivaí rivers, upper Paraná River basin, Paraná, Brazil. Check List, 2012, 8(6), 1158-1162.

CLARKE, K.R. and GORLEY, R.N. PRIMER v. 5: user manual/tutorial. Plymouth: PRIMER-E, 2001.91 p.

CRUZ, B.B., TESHIMA, F.A. and CETRA, M. Trophic organization and fish assemblage structure as disturbance indicators in headwater streams of lower Sorocaba River basin, São Paulo, Brazil. Neotropical Ichthyology, 2013, 11(1), 171-178. http://dx.doi. org/10.1590/S1679-62252013000100020.

DAVIES, P.M., BUNN, S.E. and HAMILTON, S.K. Primary production in tropical streams and rivers. In D. DUDGEON, ed. Tropical stream ecology.London: Academic Press, 2008, pp. 23-43.

ESTEVES, K.E. and ARANHA, J.M.R. Ecologia trófica de peixes de riachos. In E.P. CARAMASCHI, R. MAZZONI and P.R. PERES-NETO, eds. Ecologia de peixes de riachos. Rio de Janeiro: UFRJ, 1999, pp. 157-182. Série Oecologia Brasiliensis, vol. 6.

FARIA, A.P. and MARQUES, J.S. O desaparecimento de pequenos rios brasileiros. Ciência Hoje, 1999, 25, 57-61.

GERKING, S.D. Feeding ecology of fishes. San Diego: Academic Press, 1994. 416 p.

GRAÇA, W.J. and PAVANELLI, C.S. Peixes da planície de inundação do Alto rio Paraná e áreas adjacentes. Maringá: Eduem, 2007. 241 p.

HAMMER, Ø.; HARPER, D.A.T. and RYAN, P.D. PAST: Paleontological Statistics software package for education and data analysis. Palaeontologia Electronica, 2001, 4(1), 1-31.

HELLAWELL, J.M. and ABEL, R.A. Rapid volumetric method for the analysis of the food of fishes. Journal of Fish Biology, 1971, 3(1), 29-37. http://dx.doi. org/10.1111/j.1095-8649.1971.tb05903.x.

HURLBERT, S.H. The measurement of niche overlap and some relatives. Ecology, 1978, 59(1), 67-77. http://dx.doi.org/10.2307/1936632.

HYSLOP, E.J. Stomach contents analysis: a review of methods and their application. Journal of Fish Biology, 1980, 17(4), 411-429. http://dx.doi. org/10.1111/j.1095-8649.1980.tb02775.x.

IBAÑEZ, C., BELLIARD, J., HUGHES, R.M., IRZ, P., KAMDEM-TOHAM, A., LAMOUROUX, N., TEDESCO, P.A. and OBERDORFF, T.
Convergence of temperate and tropical stream fish assemblages. Ecography, 2009, 32(4), 658-670. http:// dx.doi.org/10.1111/j.1600-0587.2008.05591.x.

IBAÑEZ, C., OBERDORFF, T., TEUGELS, G., MAMONONEKENE, V., LAVOUÉ, S., FERMON, Y., PAUGY, P. and TOHAM, A.K. Fish assemblages structure and function along environmental gradients in rivers of Gabon (Africa). Ecology Freshwater Fish, 2007, 16(3), 315-334. http:// dx.doi.org/10.1111/j.1600-0633.2006.00222.x.

I N S T I U T O PARANAEN S D E DESENVOLVIMENTO ECONÔMICO E SOCIAL - IPARDES. Caderno Estatístico Municipio de Marialva [online]. Curitiba: IPARDES, 2016 [viewed 20 fev. 2016]. Available from: http:// www.ipardes.gov.br/cadernos/MontaCadPdf1. php? Municipio $=86990 \& b t O k=o k$

JARAMILLO-VILLA, U. and CARAMASCHI, E.P. Índices de integridade biótica usando peixes de água doce: uso nas regióes tropical e subtropical. Oecologia Brasiliensis, 2008, 12(3), 442-462.

LEGENDRE, P. and LEGENDRE, L. Numerical ecology. Amsterdam: Elsevier, 1998. 853 p.

LORION, C.M. and KENNEDY, B.P. Riparian forest buffers mitigate the effects of deforestation on fish assemblages in tropical headwater streams. Ecological Applications, 2009, 19(2), 468-479. http://dx.doi. org/10.1890/08-0050.1. PMid:19323203.

LOWE-MCCONNELL, R.H. Estudos ecológicos de comunidade de peixes tropicais. São Paulo: Edusp, $1999.535 \mathrm{p}$.

MAZZONI, R., NERY, L.L. and IGLESIAS-RIOS, R. Ecologia e ontogenia da alimentação de Astyanax janeiroensis (Osteichthyes, Characidae) de um riacho costeiro do Sudeste do Brasil. Biota Neotropica, 2010, 10(3), 53-60. http://dx.doi.org/10.1590/S167606032010000300005.

MELLES, S.J., JONES, N.E. and SCHMIDT, B. Review of theoretical developments in stream ecology and their influence on stream classification and conservation planning. Freshwater Biology, 2012, 57(3), 415-434. http://dx.doi.org/10.1111/j.13652427.2011.02716.x.

MUGNAI, R., NESSIMIAN, J.L. and BAPTISTA, D.F. Manual de identificação de macroinvertebrados aquáticos do Estado do Rio de Janeiro. Rio de Janeiro: Technical Books, 2010. 174 p.

OBERDORFF, T., GUILBERT, E., LUCCHETTA, J.-C.; GUILBERT, E. and LUCHETTA, J.C. Patterns of fish species richness in the Seine River basin, France. Hydrobiologia, 1993, 259(3), 157-167. http://dx.doi.org/10.1007/BF00006595.

OBERDORFF, T., PONT, D., HUGUENY, B. and PORCHER, J.P. Development and validation of a fish-based index (FBI) for the assessment of rivers "health" in France. Freshwater Biology, 2002, 47(9), 
1720-1735. http://dx.doi.org/10.1046/j.13652427.2002.00884.x.

PEASE, A.A., GONZÁLEZ-DÍAZ, A.A., RODILESHERNÁNDEZ, R. and WINEMILLER, K.O. Functional diversity and trait-environment relationships of stream fish assemblages in a large tropical catchment. Freshwater Biology, 2012, 57(5), 1060-1075. http://dx.doi.org/10.1111/j.13652427.2012.02768.x.

PERES-NETO, P.R., BIZERRIL, C.R.S.F. and IGLESIAS, R. An overview of some aspects of river ecology: a case study on fish assemblages distribution in an eastern Brazilian coastal river. In F.A. ESTEVES, ed. Estrutura, funcionamento e manejo de ecossistemas brasileiros. Rio de Janeiro: UFRJ, 1995, pp. 317-334. Série Oecologia Brasiliensis, vol. 1.

POOLE, G.C. Fluvial landscape ecology: addressing uniqueness within the river discontinuum. Freshwater Biology, 2002, 47(4), 641-660. http://dx.doi. org/10.1046/j.1365-2427.2002.00922.x.

POUILly, M., BARRERA, S. and ROSALES, C. Changes of taxonomic and trophic structure of fish assemblages along an environmental gradient in the Upper Beni watershed (Bolivia). Journal of Fish Biology, 2006, 68(1), 137-156. http://dx.doi. org/10.1111/j.0022-1112.2006.00883.x.

REIS, R.E., KULLANDER, S.O. and FERRARIS JUNIOR, C.J. Check list of the freshwater fishes of South and Central America. Porto Alegre: Edipucrs, 2003. $729 \mathrm{p}$.

ROSS, S.T. Resource partitioning in fish assemblages: a review of field studies. Copeia, 1986, 2(2), 352-388. http://dx.doi.org/10.2307/1444996.

SANTOS, F.B., FERREIRA, F.C. and ESTEVES, K.E. Assessing the importance of the riparian zone for stream fish communities in a sugarcane dominated landscape (Piracicaba River Basin, Southeast Brazil). Environmental Biology of Fishes, 2015, 98(8), 18951912. http://dx.doi.org/10.1007/s10641-0150406-4.

SCHLOSSER, I.J. Fish community structure and function along two habitat gradients in a headwater stream. Ecological Monographs, 1982, 52(4), 395-414. http://dx.doi.org/10.2307/2937352.

SILVA, J.C., DELARIVA, R.L. and BONATO, K.O. Food-resource partitioning among fish species from a first-order stream in northwestern Paraná, Brazil. Neotropical Ichthyology, 2012, 10(2), 389-399. http:// dx.doi.org/10.1590/S1679-62252012005000008.

SILVA, J.C., GUBIANI, É.A. and DELARIVA, R.L. Use of food resources by small fish species in Neotropical rivers: responses to spatial and temporal variations. Zoologia, 2014, 31(5), 435-444. http://dx.doi. org/10.1590/S1984-46702014000500004.

STRAHLER, A.N. Quantitative analysis of watershed geomorphology. Eos, Transactions, American
Geophysical Union, 1957, 38(6), 913-920. http:// dx.doi.org/10.1029/TR038i006p00913.

\section{SUPERINTENDÊNCIA DE DESENVOLVIMENTO}

DE RECURSOS HÍDRICOS E SANEAMENTO AMBIENTAL - SUDERHSA. Bacias hidrográficas do Paraná: uma série histórica [online]. Curitiba: SUDERHSA, 2009. [viewed 16 fev. 2016]. Available from: http://www.aguasparana.pr.gov.br/arquivos/ File/BACIAS/ivai.pdf

UIEDA, V.S. and CASTRO, R.M.C. Coleta e fixação de peixes de riachos. In E.P. CARAMASCHI, R. MAZZONI; C.R.S.F. BIZERRIL and P.R. PERESNETO, eds. Ecologia de peixes de riachos: estado atual e perspectivas. Rio de Janeiro: UFRJ, 1999, pp. 1-22. Série Oecologia Brasiliensis, vol. 6.

VITULE, J.R.S., BRAGA, M.R. and ARANHA, J.M.R. Ontogenetic, spatial and temporal variations in the feeding ecology of Deuterodon langei Travassos, 1957 (Teleostei: Characidae) in a Neotropical stream from the Atlantic rainforest, southern Brazil. Neotropical Ichthyology, 2008, 6(2), 211-222. http://dx.doi. org/10.1590/S1679-62252008000200008.

WINEMILLER, K.O., AGOSTINHO, A.A. and CARAMASCHI, E.P. Fish ecology in tropical streams. In D. DUDGEON, ed. Tropical stream ecology. Amsterdam: Academic Press, 2008, pp. 107-146.

WOlFF, L.L., ABILHOA, V., RIOS, F.S.A. and DONATTI, L. Spatial, seasonal and ontogenetic variation in the diet of Astyanax aff. fasciatus (Ostariophysi: Characidae) in an Atlantic Forest river, Southern Brazil. Neotropical Ichthyology, 2009, 7(2), 257-266. http://dx.doi.org/10.1590/S167962252009000200018.

WOLFF, L.L., CARNIATTO, N. and HAHN, N.S. Longitudinal use of feeding resources and distribution of fish trophic guilds in a coastal Atlantic stream, southern Brazil. Neotropical Ichthyology, 2013, 11(2), 375-386. http://dx.doi.org/10.1590/S167962252013005000005 .

ZENI, J.O. and CASATTI, L. The influence of habitat homogenization on the trophic structure of fish fauna in tropical streams. Hydrobiologia, 2014, 726(1), 259270. http://dx.doi.org/10.1007/s10750-013-1772-6.

Received: 12 October 2015 Accepted: 12 February 2016 